\title{
Revegetation strategies for Kaho'olawe Island, Hawaii
}

\author{
STEVEN D. WARREN AND STEFANIE G. ASCHMANN
}

Authors are research scientist, Environmental Sustainment Laboratory, US Army Construction Engineering Research Laboratories, P.O. Box 9005, Champaign, Ill. 61826-9005, and soil conservationist, Pacific Division, Naval Facilities Engineering Command, Pearl Harbor, HI 96860-7300.

\begin{abstract}
Over the past 2 centuries, the island of Kaho'olawe has suffered the ravages of war, slash-and-burn agriculture, and overgrazing. Today, much of the island is barren and severely eroded. A research project initiated in $\mathbf{1 9 8 8}$ has sought to identify effective, economical techniques to revegetate portions of the island. Treatments included drill seeding plus several rates of fertilization with monoammonium phosphate (11-52-0). Some treatments also include jute netting for soil moisture conservation and erosion control. The effect of windbreak fencing was evaluated across all treatments. Drill seeding plus broadcast application of at least 62 $\mathrm{kg} \mathrm{ha}^{-1} \mathrm{~N}$ plus $291 \mathrm{~kg} \mathrm{ha}^{-1} \mathbf{P}_{2} \mathrm{O}_{5}$ was the most cost-effective treatment. Jute netting and windbreak fencing significantly enchanced plant production, but the high cost of materials and maintenance limits their use to critical areas. The planted species with greatest promise for the windy, semiarid conditions on Kaho'olawe were buffelgrass (Cenchrus ciliaris L.), bermudagrass [Cynodon dactylon (L.) Pers.] and weeping lovegrass [Eragrostis curvula (Schrad.) Nees]. Although not included in the seed mixture, Australian saltbush (Atriplex semibaccata $\mathrm{R}$. Br.), a naturalized species, responded favorably to fertilization. A subsequent, largerscale revegetation project using a specially modified chisel plow
\end{abstract}

\footnotetext{
The authors thank Thomas Egeland, Robert Riggins, James Truax, and Eunice Vachta for their assistance in developing and conducting this project. Funding was provided by Commander, Naval Base, Pearl Harbor.

Manuscript accepted 25 Jan. 1993.
}

seeder to scarify, plant, and apply in-furrow fertilization in a single-pass operation reduced the cost and improved the results of the revegetation process.

Key Words: fertilization, jute netting, windbreak fence, drill seeding

Kaho'olawe, smallest of the 8 major islands of the Hawaiian Archipelago, suffers from a long history of natural and maninduced exposure to the forces of erosion. The island measures about $17.7-\mathrm{km}$ long by $10.5-\mathrm{km}$ wide, comprising some 11,340 ha. The highest point is the rim of an extinct volcano at $449 \mathrm{~m}$ above sea level. Kaho'olawe lies in the rain shadow of Haleakalā on Maui. Climatic records for the island are scant, but estimated annual precipitation is approximately $500 \mathrm{~mm}$ (Department of the Navy 1979), with most of it falling from November through March. In addition to the low precipitation, Kaho'olawe is the windiest of the Hawaiian Islands (Stearns 1940). Deflected by Haleakalā, the persistent northeasterly tradewinds accelerate across the intervening channel, reaching an average speed of about $9 \mathrm{~m} \mathrm{~s}^{-1}$ at Kaho'olawe (Department of Geography, University of Hawaii 1973).

Much of Kaho'olawe may have been covered with a scrub forest at one time (Cuddihy and Stone 1990). Today, however, approximately a third of the island is barren, while the remainder is dominated by the introduced shrub kiawe [Prosopis pallida (Humb. \& Bonpl. ex Willd.) Kunth] and a variety of introduced grasses and forbs. The only native species contributing significant 
biomass are pili grass or tanglehead [Heteropogon contortus (L.) P. Beauv. ex Roem. \& Schult.], ma'o or Hawaiian cotton (Gossypium tomentosum Nutt. ex Seem.), ilima (Sida fallax Walp.), 'uhaloa (Waltheria indica L.), and $\mathrm{ma}^{\prime} \mathrm{o}$ or hoary abutilon [ $\mathrm{Abu}$ tilon incanum (Link) Sweet].

The disturbance of native vegetation on Kaho'olawe probably began with slash-and-burn agriculture practiced by early Hawaiians (Kirch 1982). Intense interisland warfare before the arrival of European explorers left the island "nearly overrun with weeds, and exhausted. . .of inhabitants" (Vancouver 1798). The population had declined from an estimated peak of 800 around 1500 A.D. to approximately 60 at the time of European discovery (Hommon 1980), presumably in response to a depleted natural resource base. In 1779 the crew of Captain Cook described the island as "barren," "desolate," and an "altogether poor island"(Beaglehole 1967). The same explorers that lamented the poor condition of the island unwittingly contributed to its further deterioration by introducing goats as gifts to native monarchy, thus accelerating soil erosion. Beginning in 1859, ill-fated sheep and cattle ranches exacerbated the declining condition of Kaho'olawe. Reports over the next half-century place livestock populations as high as 20,000 sheep, 9,000 goats, and 200 head of cattle (Anonymous 1875, Bagot 1884). By 1916 approximately a third of the island was completely denuded, and from 1 to $3 \mathrm{~m}$ of topsoil had been blown or washed into the Pacific Ocean, leaving behind a wind-swept hardpan (Judd 1916).

With the entrance of the United States into World War II, Kaho'olawe was acquired by the U.S. military and became a target for offshore gunnery and aerial bombing practice. While military use of the island may have caused further deterioration in areas of intense impact, there has been no apparent increase in the size of denuded hardpan areas since military training began (Department of the Navy 1979). The U.S. Navy has, nonetheless, undertaken the responsibility to improve the condition of the island.

Transplanted grass and legume seedlings have not survived well on Kaho'olawe (Whitesell et al. 1974), perhaps due to their dependence on adequate rainfall soon after transplanting. Attempts to establish vegetation by broadcast seeding have likewise met with little success (author's observation). This manuscript describes a study, begun in 1988, aimed at identifying effective, economical measures to revegetate portions of the island.

\section{Materials and Methods}

The study site was in a broad, relatively flat swale near the center of the island. The area supported less than $2 \%$ plant cover, composed primarily of isolated clumps of Australian saltbush (Atriplex semibaccata $\mathrm{R}$. Br.). Since its introduction to Kaho'olawe around 1918 (Stearns 1940), Australian saltbush has become one of the dominant plants on the hardpan area. Soil analyses indicate that the soil of the central hardpan is predominantly of clay loam texture (Warren et al. 1988). Iron and aluminum hydrous oxides, well known for phosphorus fixation (Sanchez 1976), dominate the clay component. Nitrogen, extractable phosphorus, and organic carbon levels are very low, while potassium content is very high. Soil pH tends to be slightly acidic. The soil surface is very hard and often polished and/or striated by blowing soil particles.

To create soil surface conditions suitable for planting, the entire study site was chiseled to a depth of approximately $10 \mathrm{~cm}$ during November 1988 . The surface soil was very dry at the time of planting in December of that year. However, subsurface soil moisture conditions were surprisingly good; moisture was evident to a depth of at least $45 \mathrm{~cm}$, due to previous rains.

Five experimental blocks were established adjacent and parallel to each other. Within each block, 7 adjacent strips $60-\mathrm{m}$ long and $1.8-\mathrm{m}$ wide were laid out to accommodate 6 revegetation treat- ments and an unplanted control. All strips were oriented parallel to each other and parallel to the prevailing wind direction.

Each strip except the control was planted with a single longitudinal pass of a rangeland drill. The drill planted 5 rows in a total swath of $1.5 \mathrm{~m}$. A mixture of 6 grasses and 1 legume (Table 1) was planted at a depth of $2.5 \mathrm{~cm}$. Species selection was limited to

Table 1. Seeding rates (pure live seed) for grass and legume species included in a mixture evaluated for revegetation on Kaho'olawe.

\begin{tabular}{lc}
\hline \hline Grasses & Seeding rate \\
\hline 'T-4464' buffelgrass (Cenchrus ciliaris L.)* & $1.1 \mathrm{~kg} \mathrm{ha}^{-1}$ \\
'WW Ironmaster' yellow bluestem [ Bothriochloa & 0.6 \\
ischaemum (L.) Keng]* & 1.1 \\
Plains bristlegrass [Setaria leucopila (Scribn. \& Merr.) K. & 1.1 \\
Schum.] & 1.7 \\
Buffalograss [ Buchloë dactyloides (Nutt.) Engelm.] & 0.7 \\
NK-37' bermudagrass [ Cynodon dactylon (L.)Pers.] & 1.1 \\
Green panicgrass ( Panicum maximum Jacq. var. & \\
trichoglume) & 7.1 \\
Legume & \\
\hline Glycine [Glycine wightii (Wight \& Arnott) Verdc.] &
\end{tabular}

*De-awned

introduced species because seeds of native species were not commercially available. Cracked corn was mixed with the seed prior to planting to improve uniformity of distribution. Seeds were covered by dragging 6-cm diameter steel pipes behind the drill.

Four strips in each block were selected for fertilizer treatments. One strip was fertilized with $3.6 \mathrm{~kg} \mathrm{ha}^{-1}$ nitrogen $(\mathrm{N})$ plus $17.1 \mathrm{~kg}$ $\mathrm{ha}^{-1}$ phosphorus $\left(\mathrm{P}_{2} \mathrm{O}_{5}\right)$ applied in-furrow by the drill. Two strips were fertilized by broadcast application of $62 \mathrm{~kg} \mathrm{ha}^{-1} \mathrm{~N}$ plus $291 \mathrm{~kg}$ $\mathrm{ha}^{-1} \mathrm{P}_{2} \mathrm{O}_{5}$, and 1 strip was broadcast at $123 \mathrm{~kg} \mathrm{ha}^{-1} \mathrm{~N}$ plus $582 \mathrm{~kg}$ ha ${ }^{1} \mathrm{P}_{2} \mathrm{O}_{5}$. All fertilizer was applied as a granular form of monoammonium phosphate (11-52-0). The use of a high ratio of phosphorus to nitrogen is common in subtropical and tropical regions where phosphorus-fixation by iron and aluminum hydroxides is a problem (Sanchez 1976). Within each block, 1 unfertilized strip and 1 strip fertilized at $62 \mathrm{~kg} \mathrm{ha}^{-1} \mathrm{~N}$ plus $291 \mathrm{~kg} \mathrm{ha}^{-1} \mathrm{P}_{2} \mathrm{O}_{5}$ were covered with woven jute netting. The fabric, supplied in rolls $1.2 \mathrm{~m}$ wide, provided approximately $35-40 \%$ coverage of the soil surface. It was secured to the soil surface with $15-\mathrm{cm}$ long staples immediately following seeding and fertilization.

To evaluate the potential benefits of wind abatement on plant establishment, a single $1.2-\mathrm{m}$ tall, high-density polyethylene plastic windbreak fence was erected across the entire study site. The fence was attached to galvanized steel posts and situated perpendicular to the prevailing wind direction, approximately $12-\mathrm{m}$ downwind of the windward edge of the experimental blocks. This configuration allowed an evaluation of the effects of wind abatement in each treatment strip on both the windward and leeward sides of the fence. Elliptical apertures in the windbreak fence provided approximately $37 \%$ porosity, which is ideal for a wind barrier (van Eimern et al. 1964). To avoid disturbance associated with wind turbulence at the ends of windbreaks, the fence was extended $4.5 \mathrm{~m}$ beyond the edge of the study site on both sides.

Data were collected at the study site during January 1991, approximately 25 months after planting. A $0.25-\mathrm{m}^{2}$ quadrat was placed on the ground at 2-m intervals along the central axis of each treatment strip, beginning at the windbreak fence and proceeding to the end of the strip in both the windward and leeward directions. Percent foliar cover in each quadrat was visually estimated by species and as a total, and recorded by cover class (Daubenmire 1959). Data were summarized using class midpoints. A 3-way analysis of variance (ANOVA) was used to determine differences between treatments, blocks, and distances from the windbreak 
fence. Duncan's multiple range test was used to separate means where differences were shown to be significant in the ANOVA. The relative success of plant species across all treatments, blocks and distances from the windbreak fence was evaluated by paired comparison $t$-tests (SAS Institute Inc. 1988). The difference in percent foliar cover between any given pair of species was calculated for every quadrat, and the mean difference was tested to determine if it was significantly different from zero. The analysis was repeated for all possible combinations of species. A $95 \%$ level of probability was used for all analyses.

\section{Results and Discussion}

Twenty-five months after planting, treatments that included fertilization with at least $62 \mathrm{~kg} \mathrm{ha}^{-1} \mathrm{~N}$ plus $291 \mathrm{~kg} \mathrm{ha}^{-1} \mathrm{P}_{2} 0_{5}$ produced significantly more foliar cover than other treatments (Fig. 1). Treatment strips fertilized at $3.6 \mathrm{~kg} \mathrm{ha}^{-1} \mathrm{~N}$ plus $17.1 \mathrm{~kg} \mathrm{ha}^{-1}$ $\mathrm{P}_{2} \mathrm{O}_{5}$ had no more vegetation than the unplanted strips. Foliar

\section{Treatment}

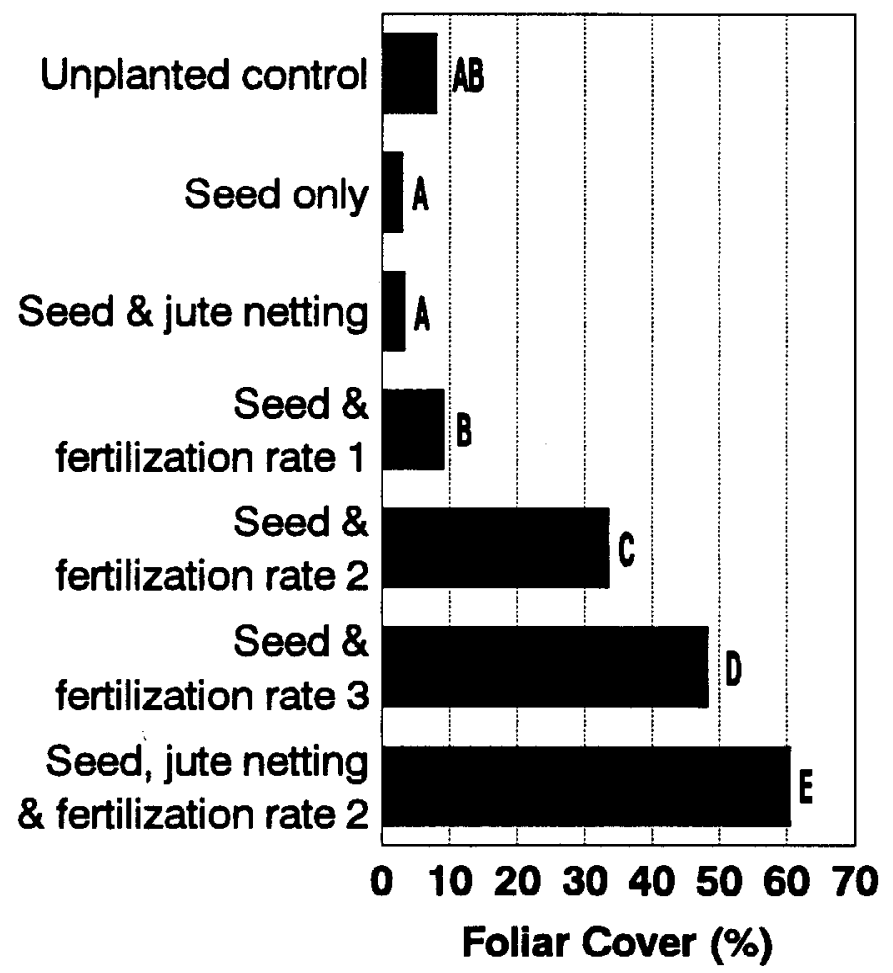

Fig. 1. Percent foliar cover by treatment, averaged across all blocks and distances from the windbreak fence, 25 months after planting on Kaho'olawe. Fertilization rate $1=3.6 \mathrm{~kg} \mathrm{ha}^{-1}$ nitrogen $(\mathrm{N})$ plus $17.1 \mathrm{~kg} \mathrm{ha}^{-1}$ phosphorus $\left(\mathrm{P}_{2} \mathbf{0}_{5}\right)$, rate $2=62 \mathrm{~kg} \mathrm{ha}^{-1} \mathrm{~N}$ plus $291 \mathrm{~kg} \mathrm{ha}^{-1} \mathrm{P}_{2} \mathbf{0}_{5}$, and rate 3 $=123 \mathrm{~kg} \mathrm{ha}^{-1} \mathrm{~N}_{\text {plus }} 582 \mathrm{~kg} \mathrm{ha}^{-1} \mathrm{P}_{2} \mathrm{O}_{5}$. Means followed by the same letter are not significantly different at $\mathbf{P}=\mathbf{0 . 0 5}$, according to Duncan's multiple range test.

cover increased as fertilization increased. The rate of increase, however, appeared to diminish between the 2 higher rates of fertilization, indicating that elevated levels of fertilization would not greatly enhance vegetation response. When applied at the maximum rate, the cost of fertilizer was approximately $\$ 560 \mathrm{ha}^{-1}$.

The most effective treatment was the combination of seed, jute netting, and $62 \mathrm{~kg} \mathrm{ha}^{-1} \mathrm{~N}$ plus $291 \mathrm{~kg} \mathrm{ha}^{-1} \mathrm{P}_{2} \mathbf{0}_{5}$. Overall, this treatment produced $61 \%$ foliar cover. Jute netting apparently conserved soil moisture and provided protection from soil erosion. Unusually heavy precipitation during the 2 nd year of the study generated large volumes of runoff that concentrated primarily on 2 of the treatment blocks. On the block that suffered the greatest damage, foliar cover for the treatment with seed, jute netting, and $62 \mathrm{~kg} \mathrm{ha}^{-1} \mathrm{~N}$ plus $291 \mathrm{~kg} \mathrm{ha}^{-1} \mathrm{P}_{2} \mathrm{O}_{5}$ averaged $51 \%$ while the next best treatment averaged only $14 \%$. Across the 3 treatment blocks that suffered only minimal erosion, the same treatment produced $63 \%$ foliar cover compared to $60 \%$ foliar cover on the next best treatment. Unfortunately, at a cost of $\$ 14,000 \mathrm{ha}^{-1}$ for materials shipped to Hawaii, use of jute netting must be reserved for critical areas where less costly methods are ineffective.

Across all treatments and blocks, significantly more foliar cover was recorded at 4 to $6 \mathrm{~m}$ downwind of the windbreak fence than anywhere else (Fig. 2). This location, centered at a downwind distance of 4 times the height of the fence, corresponds precisely with the area of greatest wind reduction recorded for other barriers of similar permeability (Heisler and DeWalle 1988). Although some degree of wind reduction has been estimated to extend up to 9 times the height of similar barriers on the windward side and up to 25 times on the leeward side (Grace 1977), the benefit in this study was limited to a range of 2 to $10 \mathrm{~m}$ on the lee side and immediately adjacent to the fence on the windward side (Fig. 2). This area corresponds roughly with a $50-70 \%$ reduction in wind velocity (Heisler and DeWalle 1988). With such a limited range of apparent benefit, windbreak fences would have to be erected with a parallel spacing of approximately $12 \mathrm{~m}$ for maximum effectiveness. The cost of materials would be approximately $\$ 5,700 \mathrm{ha}^{-1}$. Labor and maintenance add considerably to the cost. Throughout the study, the whipping action of the winds caused abrasion and tearing of the plastic fence by the metal fence posts. Sandwiching the fence between 2 lengths of wood lath prior to attaching it to the posts significantly reduced, but did not eliminate, the problem. Across all treatments, blocks, and distances from the windbreak fence, Australian saltbush provided significantly more foliar cover than any other species (Fig. 3). Even though it was not included in the seed mixture, the existing seed bank responded favorably to seedbed preparation and fertilization. The drought tolerance, prostrate growth form, and prolific seed production of Australian saltbush are desirable characteristics.

Buffelgrass ranked 2nd in foliar cover. Buffelgrass, as well as the 3rd ranking species, bermudagrass, spread by rhizomes and stolons, respectively, and their dense, mat-forming growth form make them ideal for erosion control. Both species are well adapted to the dry conditions on Kaho'olawe and have shown promise in the past (Whitesell et al. 1974). In protected areas near the windbreak fence, buffelgrass and bermudagrass sometimes formed a nearly closed canopy.

Glycine, the legume, ranked 4th in percent foliar cover. In open areas, it has a prostrate growth habit preferred for erosion control. However, in the presence of trees and shrubs, its aggressive twining or climbing habit may harm woody plants (authors' observation). Consequently, it will not be recommended for future revegetation efforts on Kaho'olawe. Siratro [Macroptilium atropurpureum (DC) Urb.], another twining legume that arrived as an apparent contaminant with the glycine seed, will be discouraged in future plantings for the same reason.

Of the remaining species, only weeping lovegrass [Eragrostis curvula (Schrad.) Nees] contributed greater than $1 \%$ cover. This species was not included in the seeding mixture, and probably arrived as a contaminant with one of the other grasses. The relative success of weeping lovegrass, despite the extremely low input, indicates that it is a species deserving attention as a candidate for future revegetation efforts on Kaho'olawe.

The less successful species occurred only occasionally on the study area and contributed only minimal foliar cover in the quadrats where they were present. However, despite their minimal contribution, some of those species consistently out-produced oth- 


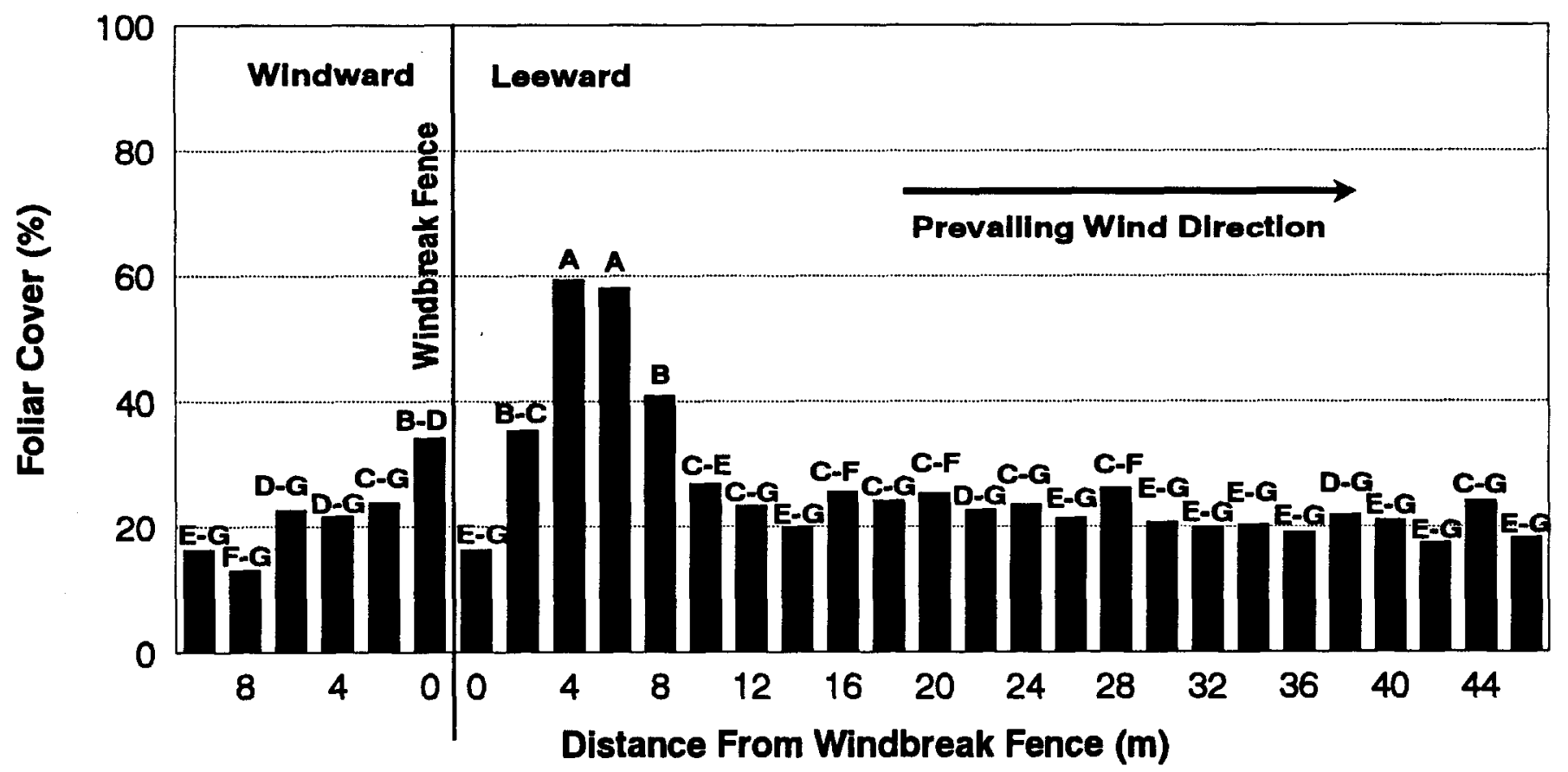

Fig. 2. Percent foliar cover by distance upwind or downwind from the windbreak fence, averaged across all treatments and blocks, 25 months after planting on Kaho'olawe. Means with the same letter are not significantly different at $P=0.05$, according to Duncan's multiple range test.

\section{Species}

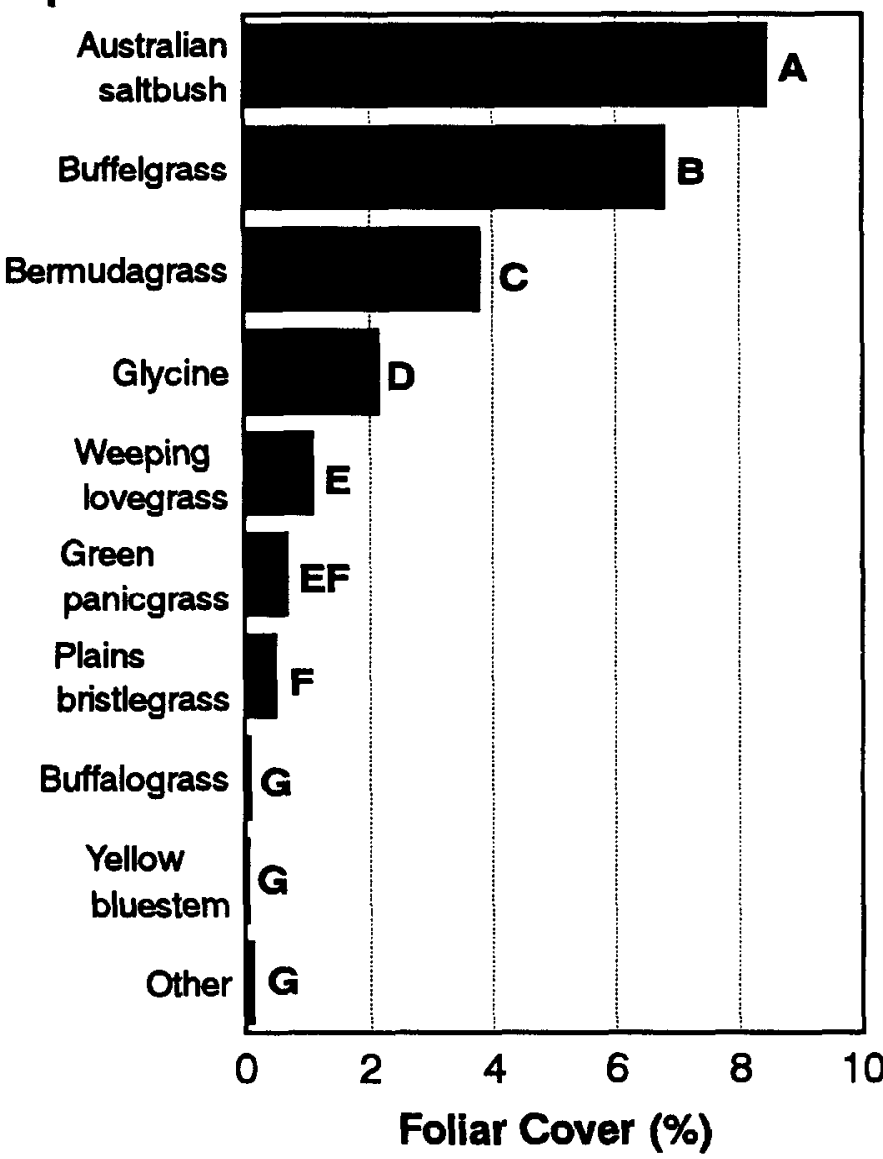

Fig. 3. Percent foliar cover of various plant species, averaged across all treatments, block, and distances from the windbreak fence, 25 months after planting on Kaho'olawe. Means followed by the same letter are not significantly different at $P=0.05$, according to paired comparison $t$-tests for all possible combinations of species. ers. Although differences in productivity sometimes met the criteria for statistical significance, the amount of foliar cover was insignificant in terms of revegetation potential, and none of those species will be recommended in the future.

Based on the information from this experiment, an 8-ha watershed on Kaho'olawe was treated in January 1990. A chisel plow seeder equipped with separate boxes for fluffy seed, fine seed, and grain and modified to include a fertilizer box was purchased. The modified drill was able to scarify the soil, plant, and fertilize in a single-pass operation, significantly reducing personnel, equipment, and fuel requirements. A mixture of 'T-4464' buffelgrass (1.1 kg PLS ha ${ }^{-1}$ ), NK-37' bermudagrass (0.67 kg PLS ha ${ }^{-1}$ ), and weeping lovegrass $\left(1.0 \mathrm{~kg} \mathrm{PLS} \mathrm{ha}^{-1}\right)$ was planted. Annual ryegrass [Lolium multiflorum (Lam.)] was included at a rate of $22.4 \mathrm{~kg}$ bulk $\mathrm{ha}^{-1}$ to produce a fast-growing cover crop. Fertilizer was applied in-furrow at a rate of $70 \mathrm{~kg} \mathrm{ha}^{-1} \mathrm{~N}$ plus $179 \mathrm{~kg} \mathrm{ha}^{-1} \mathrm{P}_{2} \mathrm{O}_{5}$ using a granular formulation of diammonium phosphate (18-46-0). In January 1992, 2 years after planting, average foliar cover on the watershed was $55 \%$ (litter from the annual ryegrass contributed an additional $17 \%$ ground cover) compared to $6 \%$ on adjacent untreated areas. The success of the project, despite the absence of windbreaks and jute netting, may be attributable, at least in part, to the increased ratio of $\mathrm{N}$ to $\mathrm{P}_{2} \mathrm{O}_{5}$ in the fertilizer, the use of a cover crop, and the addition of weeping lovegrass to the seed mixture. Weeping lovegrass contributed $31 \%$ of the total foliar cover on the watershed.

\section{Conclusions}

Adequate fertilization is the apparent key to revegetation success on Kaho'olawe. In-furrow fertilization at approximately $70 \mathrm{~kg}$ $\mathrm{ha}^{-1} \mathrm{~N}$ plus $180 \mathrm{~kg} \mathrm{ha}^{-1} \mathrm{P}_{2} 0_{5}$ provided excellent results when compared to past attempts to revegetate the island. Jute netting and windbreak fencing significantly enhanced plant production, but the high cost of materials and maintenance limits their use to critical areas where other methods are ineffective. Buffelgrass, bermudagrass, and weeping lovegrass showed the greatest potential for revegetation. Glycine, a legume, also produced significant biomass, but its aggressive climbing characteristic may threaten 
woody species. Yellow bluestem, plains bristlegrass, buffalograss, and green panicgrass showed little promise for Kaho'olawe.

\section{Literature Cited}

Anonymous. 1875. The royal excursion of His Royal Highness David Kalakaua to the bays of Piilani (in Hawaiian). Ka Lahui Hawaii, December 30, p. 4.

Bagot, F. (ed.). 1884. McKenney's Hawaiian directory. L.M. McKenney \& Co., San Francisco, Calif.

Beaglehole, J.C. (ed.). 1967. The journals of Captain James Cook on his voyage of discovery. III. The voyage of the Resolution and Discovery 1776-1780. Univ. Press, Cambridge, Mass.

Cuddihy, L.W., and C.P. Stone. 1990. Alteration of native Hawaiian vegetation. Univ. Hawaii Coop. Nat. Park Resources Study Unit, Honolulu, Hawaii.

Daubenmire, R.F.1959. A canopy-coverage method of vegetation analysis. Northwest Sci. 33:43-64.

Department of Geography, Univ. Hawaii. 1973. Atlas of Hawaii. Univ. Press of Hawaii, Honolulu.

Department of the Navy. 1979. Environmental impact statement: Military use of Kahoolawe training area. Environmental Impact Study Corp., Honolulu, Hawaii.

Grace, J. 1977. Plant response to wind. Academic Press, New York, N.Y.

Heisler, G.M., and D.R. DeWalle. 1988. Effects of windbreak structures on wind flow. Agric., Ecosyst. Environ. 22/23:41-69.
Hommon, R.J. 1980. Historic resources of Kaho olawe. National Register of Historic Places Inventory-Nomination Form. US Navy, Pacific, Div., Naval Facilities Engineering Command, Pearl Harbor, Hawaii.

Judd, C.S. 1916. Kahoolawe, p. 117-125. In: J.G. Thrum (ed.), Hawaiian Almanac and Annual for 1917. Honolulu, Hawaii.

Kirch, P.V. 1982. The impact of prehistoric Polynesians on the Hawaiian ecosystem. Pacific Sci. 36:1-14.

Sanchez, P.A. 1976. Properties and management of soils in the tropics. John Wiley \& Sons, New York, N.Y.

SAS Institute Inc. 1988. SAS/STAT ${ }^{\mathrm{TM}}$ user's guide, release 6.03 edition. SAS Inst. Inc., Cary, N.C.

Stearns, H.T. 1940. Geology and ground-water resources of the islands of Lanai and Kahoolawe, Hawaii. Territ. Hawaii, Div. Hydrogr. Bull. 6.

Vancouver, G. 1798. A voyage of discovery to the North Pacific Ocean, and round the world (1967 reproduction of the original edition). Da Capo Press, New York, N.Y.

van Eimern, J., R. Karschon, L.A. Razumova, and G.W. Robertson. 1964. Windbreaks and shelterbelts. World Meteorol. Organization Tech. Note 59.

Warren, S.D., E.G. Vachta, and W.L. Banwart. 1988. Rehabilitation proposal for Kahoolawe Island, Hawaii: An interim report. US Army Construction Engineering Res. Lab., Champaign, Ill.

Whitesell, C.D., W.H.C. Wong, Jr., and D.N.Palmer. 1974. Sixth progress report on vegetation trials for rehabilitating Kahoolawe Island, Hawaii. USDA, Forest Service, Institute of Pacific Islands Forestry, Honolulu, Hawaii. 